\title{
Miranda
}

Revue pluridisciplinaire du monde anglophone /

Multidisciplinary peer-reviewed journal on the English-

speaking world

19 | 2019

Rethinking Laughter in Contemporary Anglophone Theatre

\section{Rick Darke and Piet Oudolf, Gardens of the High Line: Elevating the Nature of Modern Landscapes.}

\section{Claire Cazajous-Augé}

\section{OpenEdition}

\section{Journals}

\section{Electronic version}

URL: http://journals.openedition.org/miranda/21498

DOI: 10.4000/miranda.21498

ISSN: 2108-6559

\section{Publisher}

Université Toulouse - Jean Jaurès

\section{Printed version}

Date of publication: 7 October 2019

\section{Electronic reference}

Claire Cazajous-Augé, "Rick Darke and Piet Oudolf, Gardens of the High Line: Elevating the Nature of Modern Landscapes.", Miranda [Online], 19| 2019, Online since 14 October 2019, connection on 16 February 2021. URL: http://journals.openedition.org/miranda/21498 ; DOI: https://doi.org/10.4000/ miranda. 21498

This text was automatically generated on 16 February 2021

\section{(c)}

Miranda is licensed under a Creative Commons Attribution-NonCommercial-NoDerivatives 4.0 International License. 
Rick Darke and Piet Oudolf, Gardens of the High Line: Elevating the Nature of Modern Landscapes.

Claire Cazajous-Augé

\section{REFERENCES}

Rick Darke and Piet Oudolf, Gardens of the High Line: Elevating the Nature of Modern

Landscapes. (Portland: Timber Press, 2017), 320 p, ISBN 978-1-60469-699-8 


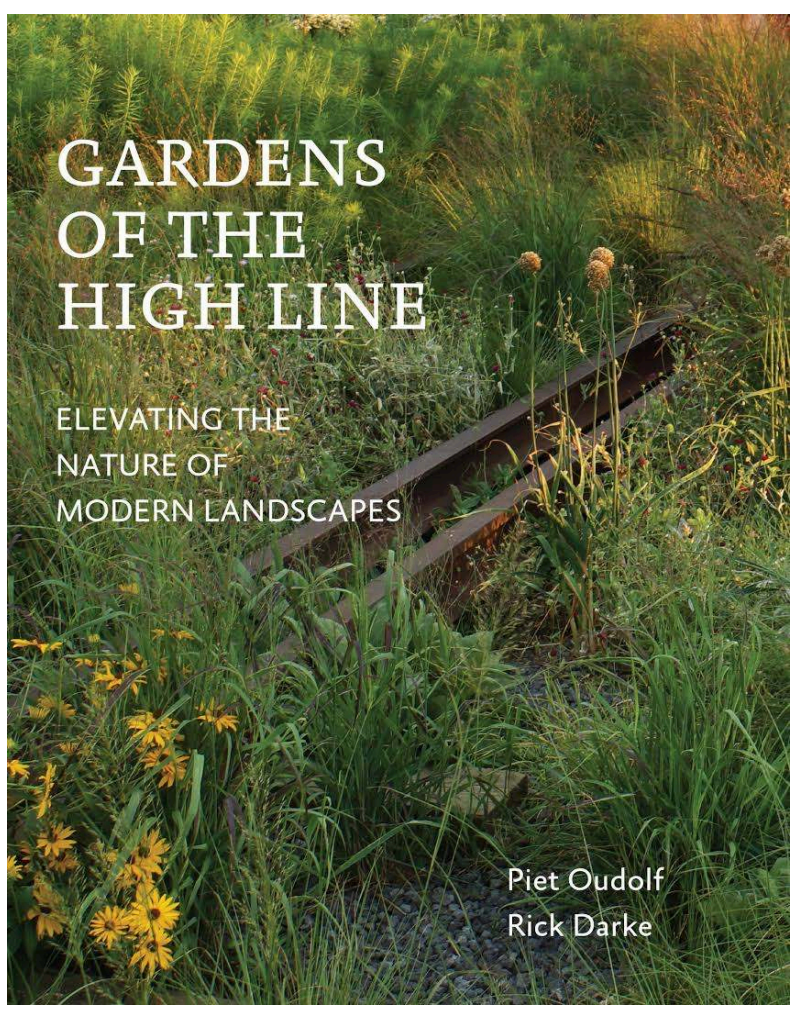

1 This richly illustrated and well-informed book is a celebration of New York City's High Line's gardens and their revolutionary philosophy. Piet Oudolf and Rick Darke present the history of the gardens, the essence of the project, its influences and its ambitions. With its hundreds of photographs, this book offers an immersive walk along these urban gardens, from the south end-Gansevoort woodland-to the north end-the Rail Yards. In a short preface, the authors write that their book aims at presenting the "design ethos [of the High Line's gardens], the patterning of their planting and the enlightened stewardship devoted to them" (17). By doing so, they hope to inspire people to create similar urban projects. As the title suggests, the gardens of the High Line are trying to "elevat[e] the nature of modern landscapes," not because they are located on the top of an abandoned elevated railway, but because their original idea and design rely on a new vision of what gardening should be.

In the introduction, Robert Hammond, co-founder and executive director of Friends of the High Line, explains that members of this association work to preserve the hybridity of the place, which is defined by the presence of wildflowers and wild grasses as well as by that of buildings and billboards. They try to make it accessible to New Yorkers by getting rid of toxic painting or by adding new drainage without jeopardizing the wild dimension of the gardens. Pietr Oudolf, who has worked as a plant designer of the gardens, has imagined planting patterns in which dying plants and new growth, winter plants and summer plants, native and introduced plants, coexist all year long. Hammond adds that the original tension of the gardens mirrors the essence of New York, a city that is both defined by its beauty and its decay.

3 The first part presents different examples of wild gardens that have preceded the gardens of the High Line, and that have influenced the landscape gardeners and designers working on this project. In 1870, William Robinson exposed alternatives to the traditional maintenance-intensive model of gardening in his seminal book The Wild 
Garden. He advocated a new approach based on a minimum of care and resources while enhancing the beauty and the durability of gardens. To do so, he looked for plants that did not need much human help or water, such as perennial plants. Garden philosopher Karl Foester also inspired the landscape gardeners to design the High Line's gardens. In his book Einzug der Gräser und Farne in die Gärten (1957), he explained how to arrange grasses in wild gardens. Instead of seeing them as weeds, he celebrated their unique beauty and encouraged gardeners to integrate them in their designs. The aesthetics of ruins-the gardens are a relic of New York's industrial landscape and its elevated lines -and the growing interest for urban exploration also influenced Piet Oudolf when he worked on the High Line's gardens. But the gardens are not the first derelict rail landscapes turned into a garden. There are other examples, such as the Bridge of Flowers in Shelburne Falls, Massachusetts, and the Promenade Plantée in Paris, but none of them has integrated dynamic living processes in its design quite as much as the High Line's gardens.

4 The following chapters explore different sections of the gardens-the Northern Spur, $10^{\text {th }}$ Avenue Square, Chelsea Thicket, the Flyover, etc.-and develop their key features. First, the landscapes of the High Line have gone through many changes and are now like a palimpsest: attentive walkers can notice the different architectural and gardening steps which have been made across the years. Then, the majority of plants are North American natives-Pennsylvania sedge, or Carex pensylvanica, Indian physic, or Portheranthus stipulatus, wild stonecrop, or Sedum ternatum, etc. Finally, the efforts made to adapt the gardens to the plants rather than to adapt the plants to the gardens give a sustainable dimension to the High Line, which have become a model of responsible gardening. The way garden designers organize the cutback of herbaceous plants illustrates their ecological ambitions and their wish to intervene as little as possible in the gardens' ecosystem. By delaying it until March, and thus leaving the garden "sleep" in winter, they allow dry foliage to naturally protect the ground and wildlife from the cold.

5 The book ends with a section on gardening. The High Line's gardens require nontraditional types of gardening. Rather than maintenance, they need "artful stewardship" (295). Gardeners-members of Friends of the High Line and employees of the New York City Department of Parks and Recreation-do not try to turn the gardens into a decorative and fixed park; instead, they have learned to care for the everchanging nature of the gardens and to adapt to their biological dynamics. The portraits of apprentice and professional gardeners observing, pruning or making subtle adjustments to the gardens which illustrate this chapter also show the democratic dimension of the High Line's gardens and the sense of community that has emerged from this project.

6 The hundreds of evocative photographs of the High Line give a broad perspective on the wild grasses, lawns, flowers, trees and wildlife of the gardens, even if, in the introduction, the authors warned the readers that it is impossible to represent the totality of the gardens. Some photographs may seem to be lacking an artistic angle: some are slightly blurred, others are underexposed, and framing sometimes seems to be erratic. Yet, this apparent lack of intervention from the photographer can be seen as a means to respect the design ethos of the gardens, which aims at reducing human intervention to a minimum-gardeners prefer self-seeded plants and do not use pesticides, and there is only remote access to support facilities, forcing gardeners to 
work with a limited number of tools. Gardens of the High Line: Elevating the Nature of Modern Landscapes succeeds in inspiring us to rethink the way we see urban gardens and provides an optimistic perspective on the manners in which we can care for nature at the age of the Anthropocene.

INDEX

Mots-clés: New York City, jardins

Keywords: High Line, New York City, gardens

\section{AUTHORS}

\section{CLAIRE CAZAJOUS-AUGÉ}

PRAG

Université Toulouse - Jean Jaurès

claire.cazajous-auge@univ-tlse2.fr 